\title{
GOAL DIRECTED BEHAVIOR AND DYSLEXIA
}

\section{Giuseppe Augusto Chiarenza}

Centro Internazionale Disturbi di Apprendimento, Attenzione e Iperattività, (CIDAAI), Milano, Italy

Corresponding Author: Giuseppe Augusto Chiarenza, Centro Internazionale Disturbi di Apprendimento, Attenzione e Iperattività, (CIDAAI), Milano, Italy

\begin{abstract}
Goal directed behavior is explained by two approaches: the first, which can be named as cybertetic (behavior is wieved as homeostatic and reflexive), and second, as cognitive approach, a learned response, (skills developed by whaching the behavior of another individual).

The aim of the paper is to present a noninvasive method described as an interaction of human beings with environment, recording the electrical activity of the brain from the human scalp.

Obtained results are in agreement of psychological theories that place at determined levels of age the acquisition of the capacities of abstract thinking and with the functional neuroanatomic studies according to which biological maturation is necessary for learning processes to develop. An acquired level of learning is in close relationship with the maturation level of the cerebral structures.
\end{abstract}

Keywords: directed behavior, dyslexia, oscilloscope

Goal directed behavior is teleologically purposive. It often seems to be a search for a goal previously defined by a model or idea in the brain (Granit 1977). Exactly how this goal is achieved, however, can vary. Formulation of strategies, their realization through actions, evaluation of results and comparisons with past experiences can be explained in different ways. Fundamentally, there are two approaches to account for purposive behavior. One is the cybernetic approach, which views behavior as homeostatic and largely reflexive (Wiener 1971). According to this model, an organism is endowed with innate patterns of behavior explained as reflexes triggered by the stimulus or as the reduction of drives.

Numerous observations have established the great power of this approach to account for many complex as well as simple behaviors in humans and other mammals, as well as in insects, fishes and birds. As we ascend the philogenetic scale, the cybernetic approach becomes unsatisfactory. Behaviors emerge that cannot be explained plausibly as innate or conditioned reflexes. For example, response learned to a specified stimulus can be elicited by generalization to a novel stimulus that activates very different afferent pathways; learned responses can be executed by using muscles that achieve the desired purpose but which were never before used for that behavior; animals and humans can learn new skills by watching the behavior of another individual.

In 1980 the Italian neurophysiologist Giacomo Rizzolatti and his colleagues have found that neurons in the rostral-ventral part of the premotor cortex of the monkey (area f5 corresponding to Brodmann 44 Broca's area in man) not only respond when they perform certain gestures like taking some peanuts, but even when they see other monkeys to perform the same gesture. These cells are called mirror neurons (Rizzolatti and Fogassi 2014). This system of neurons allows a person to recognize the 
gestures of others and their meaning thus contributing to social contact and interaction. Researchers who have studied mirror neurons have identified, since 1990, two new features of the motor system. First, it has been shown that the motor system is not active only during the actual execution of the movement, but some parts of this system are active even when the action is imagined. Secondly there are neurons that are active not only when performing a well circumscribed but when we look at another perform the same action or when we hear sounds that belong to that action. Mirror neurons therefore represent the multimodal nature of the actions, play a role in the concept of what a monkey or a man is doing and can distinguish various types of action to help their planning. The observation of the movements and actions of others also encourages imitation. Mirror neurons foster understanding of motor behavior of others, the imitation of gestures and learning actions.

The authors show that the mind is basically relational and deal with some of the practical consequences of this, for example that a child will not learn to speak by watching television.

Therefore, as one tries to explain such behaviors, another approach must be considered that assumes that higher animals possess consciousness, have ideas and can think about the significance of the information for the environment. The newborn individual can survive only by the action of species specific reflexes and homeostatic processes. As the individual develops, other mechanisms may serve to distribute information to additional regions of the brain.

In this manner multisensory and multivariate transactions begin to modulate genetically specific processes that were initially more simply determined and a cognitive model of the environment is built gradually, incorporating features of individual experience as well as species characteristic features.

One can view behavior as resulting from a cognitive process which involves an interaction between neural events representing the previous experience, the present state of the individual and the occurrence of particular features in the environment. Such behaviors consist of the attempt to match new experience against an idea reflecting past experiences. It is cognitive rather than reflexive, involving thinking rather than activation of specific neural pathways constituting stimulus response circuits (John 1980).

The aim of this paper is to present a non invasive method with which we can describe the interaction of human beings with environment, recording the electrical activity of the brain from the human scalp.

When it is the subject that begins a voluntary action to act upon or to interact with the environment and when the consequent modifications can be evaluated and compared with the preprogrammed strategies and past experience, we have all the necessary and sufficient conditions to observe the interaction between the environment and the human being and how the relative information are represented in the brain. When a subject is engaged in a self-paced, voluntary and skilled task and receives a visual feedback in real time about his motor performance, exactly as it happens in our days with videogames, a characteristic sequence of brain macropotentials can be recorded from the scalp both in children and adults.

The task is self-paced, voluntary, goaldirected and interactive. To perform it adequately, it requires the following skills: bimanual coordination, bimanual ballistic movements, adaptive programming, learning a proper timing and performance improvement. The task provides online knowledge of results and feedback (Chiarenza et al., 1982a, 1982b). In particular, the subject sat in an armchair $70 \mathrm{~cm}$ in front of an oscilloscope and held a joysticktype push button in each hand. The excursion of the button was $5 \mathrm{~mm}$. The task consisted in starting the sweep of the oscilloscope trace with the left thumb and stopping it in a predetermined area of the oscilloscope by pushing the other button with the right thumb. The sweep velocity was $1 \mathrm{~mm}$ per $\mathrm{ms}$ and the target area corresponded to a time interval between 40 and $60 \mathrm{~ms}$. The brain electrical activity associated with this task is called movement-related brain potentials.

On the basis of the spatial-temporal characteristic of these potentials and their relationship to electromyographic activity and perfor- 
mance it has been proposed that there are four successive time-periods during a skilled task (Figure 1). A premotor period that precedes the EMG activities is characterized by the Bereitschaftspotential (BP) (Kornhuber and Deecke 1965). Its amplitude is higher during skilled and goal oriented tasks than during unskilled and not purposive ones (Papakostopoulos 1978). Its scalp distribution is prevalent in the central and precentral areas. During unimanual action the $\mathrm{BP}$ is predominantly on the contra lateral hemisphere, while during bimanual skilled action is symmetric in the right hand subjects but not in the left hand subjects (Papakostopoulos 1980a). This potential seems to reflect the strategic organization of the ideokinetic elements necessary to achieve the goal. The sensory motor period starts from the onset of EMG activities and lasts for $80 \mathrm{~ms}$ after the peak of the EMG. It is during this period that behaviour is manifested. During this period the electrical cerebral activity is dominated by a further negative potential, Motor Cortex Potential (Papakostopoulos and Crow 1984). This potential seems to be an index of reafferent peripheral activity. This potential is followed by the $\mathrm{N} 100$, the expression of the early stages of visual perceptual processing of the brain response to the visual stimulus, i.e. the oscilloscope's sweep.

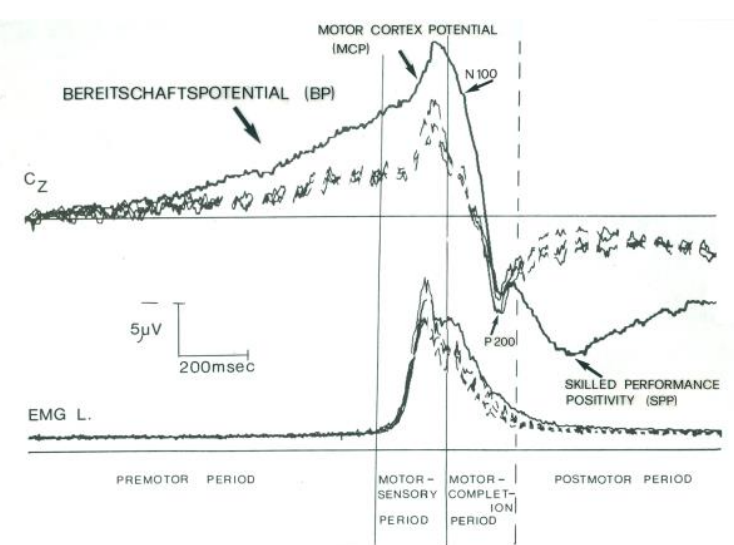

Figure 1 -Movement related potentials and left forearm electromyograms during unskilled (- - ) and skilled (- actions, recorded from the vertex $(C z)$. Modified from Papakostopoulos 1978 J. of Physiology

The motor completion period is characterized by the decline of the EMG activities and by a positive peak with a latency of $200 \mathrm{~ms}$ : P200 (Vaughan et al. 1968). During this period the visual evoked potential, evoked by the sweep of the oscilloscope, during a motor perceptual task is suppressed in the precentral areas (Papakostopoulos et al. 1975).

The postmotor period is characterized by the return of the electromyographic activities to the preceding rest conditions and by a presence of a large positive potential with a latency of $460 \mathrm{~ms}$ denominated skilled performance positivity (SPP) (Papakostopoulos 1980b). This potential has a central and parietal scalp distribution. It is observed in healthy subjects, when they are asked to perform a motor perceptual task that requires precision, timing, and improvement of performance level by providing adequate real time feedback information on the outcome. The SPP is absent during unskilled tasks and when adequate feedback is not provided to the subject (Papakostopoulos 1986). From a chronological standpoint it may be said that the SPP coincides with the subject's awareness of the success or failure of his performance. This positivity appears when the subject looks for information about his outcome, that it is to say, information relevant to the efficiency of his psychomotor pre-programmed organization. The knowledge of the outcome is likely to be used to influence future actions.

The various stages of organization of goal directed behaviour can be appreciated following the developmental features of the Movement Related Potentials from childhood to adult life. (Figure 2)

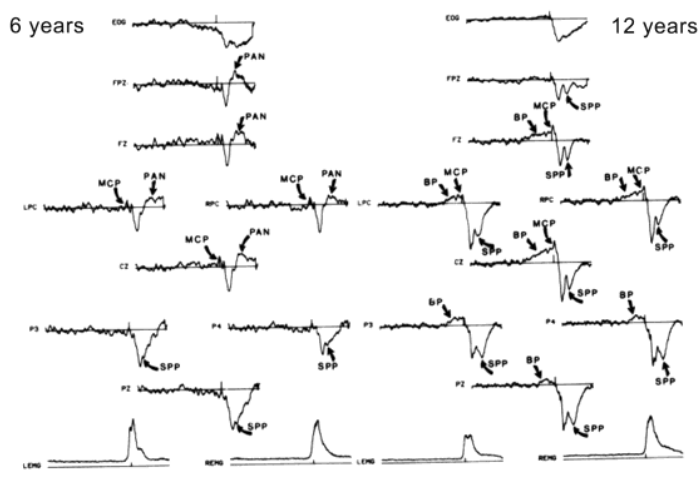

Figure 2 -Figure 2 shows the averaged movementrelated brain potentials during the execution of a complex motor perceptual task, in normal subjects of 6 and 12 years old, along with (bottom) left arm (LEMG) and right arm (REMG) electromyographic activity. In this and following figures, $B P=$ Bereitschaftspotential; $M C P=$ Motor Cortex Potential, SPP $=$ Skilled Performance Positivity; PAN = Post Action Negativity 
In children of six-seven years, only MCP N100 and P200 are present; they represent the sensory information coming from the subject and environment. Therefore, in spite of the awareness of the movement carried out by the children, the BP characteristic of the preparatory period, is absent in these young subjects. At these ages, during the postmotor period, another potential is recorded with a negative polarity, denominated Post-Action Negativity (PAN) most prominent in the frontal and central regions, while the SPP is present only in the posterior areas. This negativity might indicate the preconceptual stage of the representational intelligence in which the reality depends and extinguishes in the moment of the immediate perception (Inhelder and Piaget 1958). In these children the surprise or the novelty about the outcome of the performance predominates. PAN decreases with age and disappears by the age of 8-9; in parallel, the BP and SPP start to emerge in the frontal and central areas. During this period of age, the children acquire the adult capacity of abstract thinking. They conceive many possible ways in which they could operate and many alternative ways in which they could be better. We suppose that these different possibilities, these strategic qualities, i.e. the intentionality of action to achieve a goal are reflected in the BP amplitude. Furthermore after eleven years of age thinking is propositional (Inhelder and Piaget 1958). In the period of formal operation the children take the outcome of their performance, put them in sentence form, and begin to find relationships between sentences. According to this view, the emergence of SPP in frontal areas corresponds to a new way of brain functioning: the outcome and the knowledge of results are used to match them with the projects and past experience in order to improve the goal directed behaviour.

Ageing affects these potentials. In particular, the MCP slowly decreases in amplitude and disappears, the SPP also decreases in amplitude and slightly increases in latency. The BP seems not to be affected by ageing (Chiarenza 1993).

One clinical aspect of dyslexia that has been little explored is the lack of fluency and prosody during reading, namely aspects related to the organization of movement. Various diffi- culties in the execution of neuromotor acts, such as simple repetitive movements or alternating complex movements such as bimanual coordination have long been observed in dyslexic children. Furthermore, clinical signs such as dysrhythmia, the presence of synkinetic movements, have often been described in dyslexic individuals (Adams et al.1974, Kennard 1960, Rutter et al., 1966, Stine et al., 1975, Wolff and Hurvitz, 1973, Denckla 1973). These difficulties were interpreted as a disorder of the temporal organization of motor skills (Klicpera et al., 1981, Denckla 1973). These observations were also recently confirmed by Punt et al. (2010), who reported that $87 \%$ of dyslexics exhibit minor neurological dysfunction, especially in fine manipulative skills, the regulation of muscle tone, and the excessive presence of associated movements. All of these observations support the hypothesis of an important involvement of cerebellar function in reading and writing. It is therefore possible to maintain that we are facing a considerable heterogeneity in the dysfunction of skills in dyslexic children, not only visual and auditory, but also motor: Nicolson and Fawcett (2005) stated that children with dyslexia show difficulties when they have to acquire new skills quickly and fluently, and when they have to assemble two or more actions.

In our opinion, the reason for the neglect of the motor component of dyslexia lies in the fact that all experimental designs, both neurophysiological and behavioural, were built on the stimulus-response model. This is able to describe only phenomena that occur in the interval between the stimulus and the response of the subject, without being able to observe the phenomena before the onset of the stimulus and after the onset of the response. In this way, only phenomena related to the processing of auditory and visual stimuli have been described.

To study in detail the organization of a motor act, both simple and complex, such as reading and writing, it is necessary to devise other experimental models that take into account not only what happens during the processing of a stimulus, but also phenomena that take place before and after it. This is the fundamental and unique contribution of movement related potentials. Therefore, the performance 
of a complex perceptual-motor task appears to be particularly well suited to provide information on those systems and subsystems that regulate and organize the functions of reading and writing (Chiarenza et al., 1982a). In addition, since the assumptions in dyslexia predict poor reading skills, a test of perceptual-motor skills, which lies outside the domain of reading, would be particularly suitable to test this hypothesis.

Using this task, we have shown that dyslexic children, besides being slow and not very accurate from a behavioural point of view, present a deficit of programming movements, a deficit of visual and kinaesthetic sensory processes, a deficit and a reduced capacity to evaluate their performance and correct their errors (Figure 3, 4, 5) (Chiarenza 1990, Chiarenza et al. 1982a, 1982b, 1986, 2006, Casarotto et al. 2007).

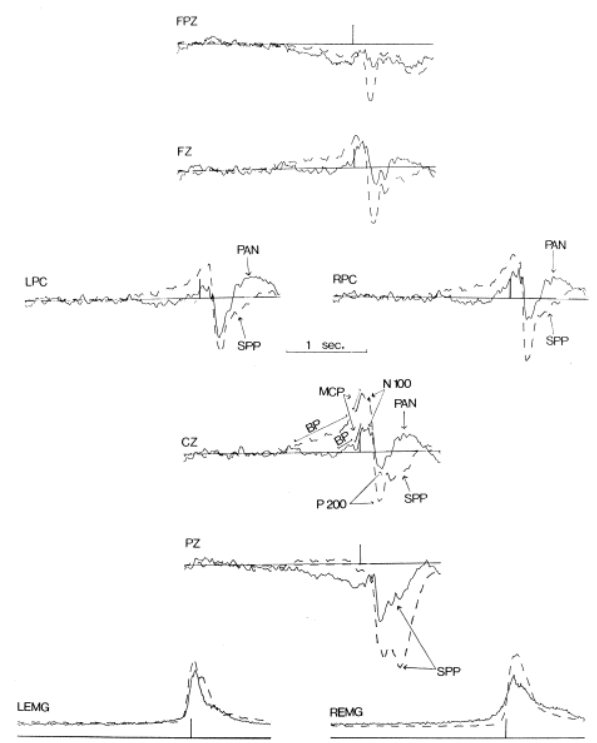

Figure 3 - Figure 3 shows the average movementrelated brain potentials during the execution of a complex motor perceptual task, in normal subjects (thin line) and dyslexic subjects (thick line), recorded in $F p z$ ( $F p z=$ middle prefrontal), $F z(F z=$ middle frontal), and $P z(P z=$ middle parietal $)$, along with (bottom) arm electromyographic activity (EMG).

Dyslexic subjects showed a reduced BP amplitude of very short duration, indicating a non-adequate preparation. MCP reduced amplitude, indicating a lack of kinesthetic processing; N100 and reduced $P 200$ amplitude indicating a deficit of visual perception and reafferent activity respectively; SPP reduced amplitude on the parietal regions and the presence of PAN on the central and frontal regions suggesting a reduced ability

to evaluate target performance and non-target performance respectively (for more details see

Chiarenza Journal of learning disabilities, 1990)
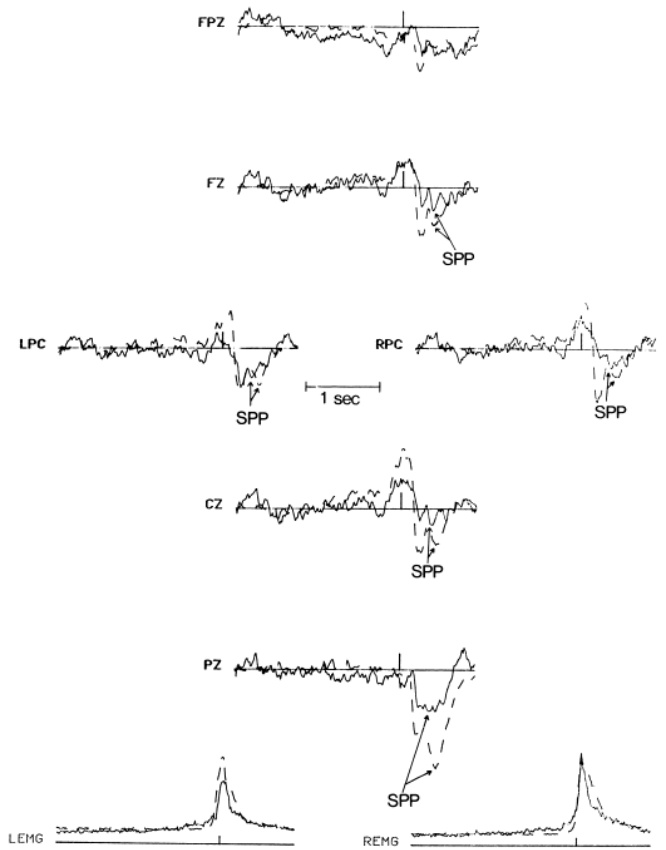

Figure 4 -Figure 4 shows the average of the movementrelated brain potentials associated with target performance in normal subjects (dashed line) and dyslexic subjects (continuous line). The potential associated with knowledge of results $(S P P)$ is present in all areas of the brain but of reduced amplitude
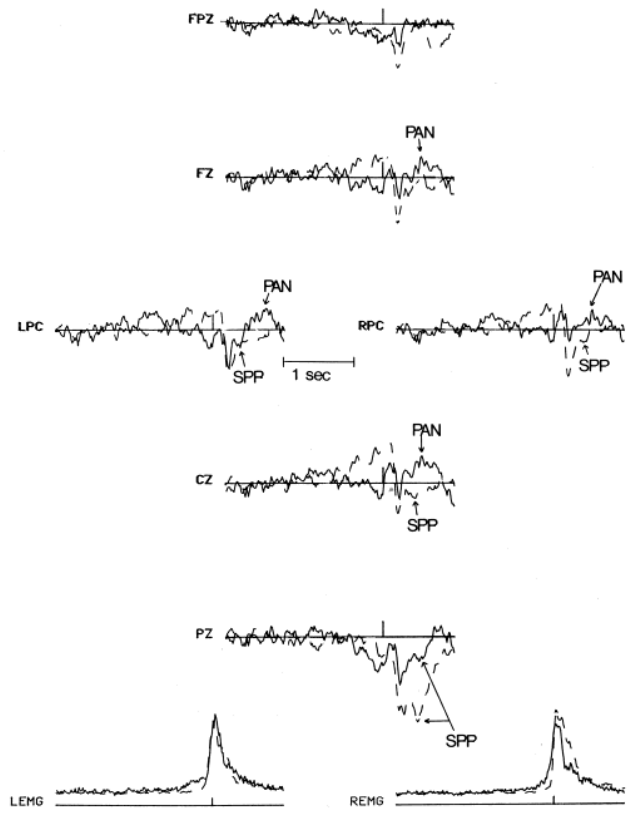

Figure 5 - Figure 5 shows the average of the movementrelated brain potentials associated with non-target performance in normal subjects (dashed line) and dyslexic subjects (continuous line). The potential associated with the assessment (SPP) is only present on the parietal areas (perceptual activity), while on the central and frontal areas a negative potential (PAN) is recorded, expression of the failure to process the error

(Chiarenza 1990) 
These studies clearly demonstrate that dyslexia is not only a phonological or a gestalt deficit, but also a praxic disorder in which praxic abilities, such as motor programming, sequential and sensory-motor integration and evaluation processes, are required and somehow defective in dyslexia (Chiarenza et al. 2014). Dyslexia can be defined from a psychophysiological point of view, as a disorder of programming and integrating ideokinetic elements, associated with a deficiency in the fast processing and integration of sensory information, with a reduced efficiency of error systems analysis. All these phenomena occur at different levels of the central nervous system and at different times during reading (Chiarenza 1990; Chiarenza et al. 1982a, 1982b, 1986).

All these results are in agreement with the psychological theories that place at determined levels of age the acquisition of the capacities of abstract thinking and with the functional neuroanatomic studies according to which a biological maturation is necessary for learning processes to develop. An acquired level of learning is in close relationship with the maturation level of the cerebral structures. When these structures due to different conditions are not able to accomplish their functions, the behaviour is always affected during its preparatory period, or its realization or its evaluation period.

\section{REFERENCES}

1. Adams, R.M., Kocsis J.J., Estes R.F., 1974. Soft neurological signs in learning disabled children and control. Amer. J. Dis. Child. 128, 614-618.

2. Casarotto, S., Ricciardi, E., Sani, L., Guazzelli, M., Pietrini, P., Chiarenza, G.A., 2007. Single-letter reading elicits a different spatio-temporal modulation of brain activity in dyslexic children as compared to healthy controls, Neuroimage, 36 suppl. 1), 171 TPM.

3. Chiarenza, G.A., 1990. Motor-perceptual function in children with developmental reading disorders: neuropsychophysiological analysis. J Learn Disabil. 23, 375-385.

4. Chiarenza, G.A., 1993. Movement Related brain macropotentials of subjects with Down syndrome during skilled performance. American Journal of Mental Retardation, Vol. 97, No. 4, 449-467.

5. Chiarenza, G.A., Papakostopoulos, D., Guareschi Cazzullo, A., Giordana, F., Giammari Aldè, G., 1982a. Movement related brain macropotentials during skilled performance task in children with learning disabilities. In: Chiarenza G.A. Papakostopoulos, D. (Eds.), Clinical Application of Cerebral Evoked Potentials in Pediatric Medicine. Excerpta Medica, Amsterdam, pp. 259-292.

6. Chiarenza, G.A., Papakostopoulos, D., Guareschi Cazzullo, A., Giordana, F., Giammari Aldè, G., 1982b. Movement related brain macropotentials (MRBMs) and their relationship with the accuracy of skilled performance in normal and learning disabled children. In: A. Rothenberger (Ed.), Event Related Potentials in Children. Basic concepts and clinical applications. Elsevier Biomedical Press, Amsterdam, pp. 243-256.

7. Chiarenza, G.A., Papakostopoulos, D., Grioni, A.G., Tengattini, M.B., Mascellani, P., Guareschi Cazzullo, A., 1986. Movement-related brain macropotentials during a motor perceptual task in dyslexic-dysgraphic children. In: McCallum, W.C., Zappoli, R. and Denoth, F. (Eds.) Cerebral Psychophysiology: Studies in Event-Related Potentials (EEG Suppl. 38) Elsevier Science Publisher B.V., Amsterdam, pp. 489-491.

8. Chiarenza, G.A., Olgiati, P., Trevisan, C., Casarotto, S., 2006. Preparatory and pre-lexical periods in dyslexic children: a reading-related potential study. Int $\mathbf{J}$ Psychophysiol. 58 (2-3), 303.

9. Denckla, H.B., 1973. Development of speed in repetitive and successive finger-movements in normal children. Dev Med Child Neurol. 15, 635-645.

10. Granit, R., 1977. The purposive brain. MIT Press, Cambridge, Mass.

11. Inhelder, B. Piaget, J., 1958. The growth of logical thinking from childhood to adolescence. Basic Book Inc., New York.

12. John, E.R., 1980. A neurophysiological model of purposive behavior. In: Thompson, R.F., Hichs, L.H., Svirkov, V.B. (Eds.) Neural mechanism of goaldirected behavior and learning. Academic press, New York, 118-135.

13. Kennard, M., 1960. Value of equivocal signs in neurological diagnosis. Neurology 10, 753-764.

14. Klicpera, C., Wolff, P.M., Drake, C., 1981. Bimanual co-ordination in adolescent boys with reading retardation. Dev Med Child Neurol. 23, 617-625.

15. Kornhuber H.H., Deecke L., 1965. Hirnpotentialänderungen bei Willkürbewegungen und passiven Bewegungen des Menschen: Bereitschaftspotential und reafferente Potentiale. Pfluegers Arch Ges Physiol; 284: 1-17.

16. Nicolson, R. I., Fawcett, A. J., 2005. Developmental Dyslexia, Learning and the Cerebellum. Journal of Neural Transmission Suppl. 69, 19-36.

17. Papakostopoulos, D., 1978. The serial order of selfpaced movement in terms of brain macropotentials in man. J. Physiol. 280: 70-71

18. Papakostopoulos D., 1980a. The Bereitschaftspotential in left and right-handed subjects. In: Kornhuber H.H., Deecke L. (Eds.) Motivation, motor and sen- 
sory processes of the brain: electrical potential, behaviour and clinical use. Elsevier North Holland, Amsterdam pp. 234-241.

19. Papakostopoulos, D., 1980b. A no stimulus, no response event-related potential of the human cortex. Electroenceph clin Neurophysiol, 48: 622-638.

20. Papakostopoulos, D., 1986. MRBM during skilled performance with and without feedback of knowledge of results. In: McCallum, W.C. Zappoli, R., Denoth, F. (Eds.) Cerebral Psychophysiology: Studies in Event-Related Potentials (EEG Suppl. 38) Elsevier Science Publishers B.V., Amsterdam, pp. 485-487.

21. Papakostopoulos D, Crow HJ., 1984. The precentral somatosensory evoked potential. In: Karrer R, Cohen $\mathrm{J}$, Tueting, editors. Brain and Information. Eventrelated potentials (Vol 425, pp 256-261), New York: Annals of the New York Academy of Science.

22. Papakostopoulos, D, Cooper, R., Crow, H.J. 1975. Inhibition of cortical evoked potentials and sensation by self-initiated movement in man. Nature, 258: 321324.

23. Punt, M., Jong, D.E. M., D.E. Groot, E., HaddersAlgra 2010. Minor neurological dysfunction in children with dyslexia. Dev Med Child Neurol. 52(12), 1127-32.

24. Rizzolatti, G., Fogassi, L. 2014. The mirror mechanism: recent findings and perspectives. Philos Trans R Soc Lond B Biol Sci., Apr 28; 369 (1644): 20130420. doi: 10.1098/rstb.2013.0420.

25. Rutter, M., Graham P., Birch, M.G., 1966. Interrelations between choreiform syndrome, reading disability and psychiatric disorder in children of 8-11 years. Dev Med Child Neurol. 8, 149-159.

26. Stine, D.C., Saratsiotis, J.M., Mosser, R.S., 1975. Relationship between neurological findings and classroom behaviour. Amer J Dis Child. 129: 10361040.

27. Vaughan, G.H.Jr., Costa, L.D., Ritter, W. 1968. Topography of the human motor potential. Electroenceph clin Neurophysiol. 25: 1-18.
28. Wiener, N., 1971. Cybernetics or control and communication in the animal and the machine. MIT Press, Cambridge, Mass.

29. Wolff, P.N., Hurwitz, J., 1973. Functional implications of the mentally brain damaged syndrome. Semin. Psychiat 5, 105-115.

\section{Резиме}

\section{ЦЕЛНО НАСОЧЕНО ОДНЕСУВАЊЕ И ДИСЛЕКСИЈА}

\section{Џузепе Аугусто Кијаренца}

Меѓународен центар за проучување на нарушувањата, вниманието и хиперактивноста, Милано, Италија

Целното насочено однесување се објаснува со два пристапа: првиот кој може да се нарече кибертетски (на однесувањето се гледа како на хомеостатско и рефлексивно) и, вториот, како когнитивен пристап, научен одговор, (вештини развиени со гледање на однесувањето на друго лице).

Целта на трудот е да се претстави неинвазивна метода опишана како интеракција на луѓето со средината, снимање на електричната активност на мозокот од човечкиот скалп.

Добиените резултати се во согласност со психолошките теории кои на утврдени нивоа на возраст го ставаат стекнувањето на капацитетите на апстрактно мислење и со функционалните невроанатомски студии според кои биолошкото созревање е неопходно за да се развие процесот на учење. Стекнатото ниво на учење е во тесна врска со нивото на созревање на церебралните структури.

Клучни зборови: насочено однесување, дислексија, осцилоскоп 